\title{
Challenges of Teacher Autonomy for Professional Competence
}

\author{
Purna Bahadur Kadel, \\ kadelpurna@yahoo.com \\ Associate Professor \\ Central Department of Education \\ Tribhuvan University
}

\begin{abstract}
Teacher autonomy is essential for their professional competence. Unless they are accountable at their profession, there will not be any positive output in the domain of teaching and learning. The main objectives of this study were to explore the teachers' perceptions on the impact of teacher autonomy in enhancing their professional competences, to identify how far the level of teacher autonomy affects the professional competences of the teachers, and to investigate the existing practices of teacher autonomy at Tribhuvan University. The phenomenological research design was adopted to accomplish this study. Ten English teachers at least 2 from each of 5 constituent colleges of Tribhuvan University were selected as a sample using purposive non-random sampling procedure to collect data. Semi-structured in-depth interview and classroom observations were administered as tools to elicit data to address the objectives of this study. The findings were obsolete of teaching and learning activities and classroom management due to the lack of online digital books and articles in the library, lack of blended between online Moodle and face to face mode of pedagogy, lack of technological pedagogical and content knowledge, no teacher autonomy in curriculum designing, and no grants for travelling and lack of daily allowances to teachers to attend the conference, seminar, and workshop at home and abroad.
\end{abstract}

Key Words: teacher autonomy, phenomenology, obsolete, blended, Moodle, and professional competence

\section{Introduction}

Teacher autonomy is an essential aspect for teacher professional development at the University level; however, it has been less practiced area of the study at Tribhuvan University particularly. Teacher autonomy is considered as one of the most important issues in education. Teachers need freedom and flexibility for their professional development. Teacher autonomy is generally defined as teachers having control over their own professional development and practice particularly interdependence in their own context. Teachers need to make autonomous decisions for how they plan to teach; what they practice; and how they can improve their teaching (Dikilitas \& Griffiths, 2017). In fact, teacher autonomy is associated with institutional and classroom management with 
given curricula (Benson, 2008). It enables them to develop required skills, expertise, knowledge and attitudes to be self-directed professional teachers (Sehrawat, 2014). The output of teaching and learning depends on the teachers at the university. If the teachers' autonomy is recognized and acknowledged by the authority of the university, their professional competences can be enhanced and thereby increasing their performances in the classroom which uphold the prosperity of the university so the teachers need to act and perform certain responsibilities autonomously pertaining the curriculum modification as per the context, pedagogical practices, assessment systems, classroom management and professional development (Fachrurrazi, 2017).

Moreover, teacher autonomy refers to teachers' self-regulation, professional competence and freedom from externally imposed agendas (Castle \& Aichele, 1994). In teacher autonomy, there is full-fledged liberty for the teachers to act professionally and to choose the teaching methods, teaching strategies, and assessment models which help them to enhance their professional development. In this regard, Little (1995) argues teacher autonomy as the capacity to engage in self-directed teaching or professional action. The autonomous teachers can develop their professional career being self-directed teachers. They can involve various activities, such as creative writing, taking part in conference, workshop, seminar etc. Autonomy refers to acting freely with a sense of volition and choice of the teachers. Teacher autonomy includes the absolute freedom in choosing curricula, syllabuses, contents and teaching materials, teaching methods and type of assessment in the formative and summative evaluation at the university. Teacher autonomy can be curriculum designers, implementers, administrators, assessors, bridgers etc. (Schibeci \& Hickey, 2003).

Teachers' academic freedom associated with accountability to the concerns of truth and generation of new knowledge that has to remain very significant in the system of higher education (Prakash, 2011). It is a buzz topic even at the educational discourses and language conferences and seminars. Teacher autonomy is one of the major issues for the empowerment of teachers at the university and school education (Benson, 2000). Teacher autonomy is essential for ensuring a learning environment that addresses children's diverse needs. It is driven by a need for personal and professional improvement in order to seek out opportunities over the course of his/her career to develop further. In fact, autonomous teachers feel personal responsibilities to attend workshops, seminars and conferences and come up with new classroom ideas for their professional competences to develop appropriate skills, knowledge, and attitudes. The teacher should have the freedom to innovate and to devise appropriate methods of communication and activities relevant to the needs and capabilities of the concerns of the community (Sehrawat, 2014).

Wilches (2007, as cited in Paulsrud, 2018) argues that interdependence, accountability, and commitments are the important elements in autonomous behaviors of teachers. Teacher autonomy helps then to increase their efficiencies in teaching and learning, particularly on their subject matters. In course of teachers' autonomous life, they should choose the project and professionally oriented teaching methods, strategies, styles, assessment, and curricula of different levels through self-consciously from a wide range of eligible alternatives and making something out of their lives as per their own understandings for valuable and worth doing (Wall, 2003, as 
cited in Benson, 2008). Teacher autonomy reflects teachers' capacities to lead such lives or to some conditions of contextual freedom that facilitates the exercises of their capacities (Benson, 2008). Teacher autonomy can be achieved through engagement in critical reflection which helps for liberation and empowerment of teachers with enhanced interest and ability to overcome contextual constraints in teaching and learning context (Vieira, Barbosa, Paiva, \& Fernandes, 2008). Teacher autonomy makes the teachers capable and professionally sound. It helps them to be accountable in their professional careers. More importantly, they can share their experiences through the professional platforms for their professional competences.

Benson (2001) argues that there are two types of teacher autonomy viz. proactive autonomy and reactive autonomy. Proactive autonomy might be understood as control over methods and contents; however, reactive autonomy is associated with methods of teaching and learning. Learner autonomy is self-regulated in learning in which the learners involve in self-making decisions, such as learning objectives, choice of learning strategies etc. Likewise, teacher autonomy is also self-directed in teaching methods, styles, assessments, doing researches, taking part in conferences, seminars, workshops for their professional development (Holec, 1981, as cited in Trebbi, 2008). Teacher autonomy is connected with teachers' rights to freedom from control of the authority in engaging for their own self-directed teaching and learning. Benson (2000, as cited in Shaw, 2017) suggests that the exercise of teacher autonomy is possibly constrained by

- Policy factors

- Institutional factors

- Conceptions of language including dominant conceptions of what the target language and ideologies of correct and standard usage

- Language teaching methodologies defined in terms of academic expertise and professional assumptions (p.116).

\section{Statement of Problem}

Tribhuvan University is the largest and the oldest university in Nepal which provides academic contributions to most of the students through its constituent and affiliated campuses across the country. However, teaching faculties are not given as much for teacher autonomy as they would need in every activity in the university. The university authority has not granted the fullfledged autonomy, such as selecting contents in the syllabus, freedom of decision making in the examination, taking part in the conference, seminar, and workshop, freedom of administering assessment etc. Being a faculty in the university, I have felt lack of teacher autonomy in the university. Teachers should be given power of decision-making process in their teaching careers (Friedman, 1999, as cited in Fachrurrazi, 2017). Teachers' competence in teaching is affected by the level of teacher autonomy which has been granted them by the institution. Teachers with high levels of autonomy have high levels of competence in teaching and vice versa. Teacher professional competence depends on the level of teacher autonomy (Fachrurrazi, 2017). By increasing teacher autonomy, teacher would feel very passionate in working. As a result, teacher will work very creatively and independently (Blasé \& Kirby, 2009, as cited in Fachrurrazi, 2017). 


\section{Objectives of the Study}

The objectives of this study were as follows:

- To explore the teachers' perceptions on the impact of teacher autonomy in enhancing their professional competences

- To identify how far the level of teacher autonomy affects the professional competences of the teachers

- To investigate the existing practices of teacher autonomy at Tribhuvan University

\section{Methodology}

This is a qualitative research. Phenomenological research design was adopted to carry out this study. Qualitative approach was used to analyze and interpret the data in this study. Semistructured in-depth interview and classroom observation were used as tools to collect required data to address the objectives in this study. Ten teachers who have been teaching English were selected using purposive non-random sampling procedure from five constitute colleges of Tribhuvan University. Two English teachers from each college were selected to elicit data since it is a qualitative research. Moreover, I conducted their classroom observations to find out the practices of teacher autonomy in English classes. I conducted classroom observation using diary notes based on the observation protocol. I observed at least one class of five teachers to find out whether they practiced the teacher autonomy in the class or not.

Instead of genuine names, I gave them the pseudo ones to maintain the anonymity while analyzing and interpreting data. To share their experiences freely without any pressure and stress, I created conducive environment during the data collection period. The respondents were ensured that their information would not be misused and twisted for any other purposes beyond this study. I prepared the guideline questionnaire for employing semi-structured in-depth-interview to the teachers. The recorded interviews were transcribed into written text. To maintain the trustworthy and authenticity of the raw data member check was used (Cohen, Manion, \& Morrison, 2007).

\section{Analysis of Data}

Having administered semi-structured in-depth interview and conducting classroom observation, I prepared 40 common codes from 10 respondents regarding the professional competence through teacher autonomy. Subsequently, I have developed 15 common basic themes out of 40 similar codes. Again I have merged similar common basic themes into 7 organized themes, such as freedom of using teaching methods and techniques, using different teaching strategies and styles, free to launch assessment, freedom of the selection of teaching and learning materials, classroom management, participation in the preparation of curriculum, participation in conference, conducting seminar and workshop, involvement in policy making process, impact of teacher autonomy on professional competence, and participation in the administrative activities. Finally, I have integrated them into 6 global themes which are analyzed and interpreted in the results and discussion section as follows: 


\section{Results and Discussion}

Teaching and Learning Activities and Classroom Management

The teachers who have been teaching in the constituent campuses of Tribhuvan University are very aware regarding the new methods, approaches and techniques. Most of the faculty members of English have the expertise to integrate Information Communication Technology (ICT) and content knowledge in the classroom pedagogy. In this regard, T3 argues that

due to the lack of regular supply of high server of internet and power, it is very difficult to browse the required materials in the classroom. Due to the lack of constant and consistency of internet, I feel uncomfortable to integrate virtual and face to face mode of pedagogy to make the effective teaching and to develop myself as ICT friendly teacher. The libraries of constituent colleges are still traditionally running without any online journals and books so we teacher cannot be updated with the global ELT scenarios.

Teacher autonomy is essential for professional competence. If the teachers were provided ICT training for the classroom pedagogy freely, it would be very useful and effective for their professional competence. In similar vein, T5 argues that "we are given autonomy to use any type of methods and techniques; but we are not enlightened with ICT integrated exposure in the campus". Teacher autonomy is associated with the ICT pedagogy so that teachers can grow themselves professionally. Teachers have freedom of choices of applying any current method and technique in the classroom for their professional growth as well as betterment of learners (Sehrawat, 2014; Benson, 2001). However, they are unable to use of Technological Pedagogical and Content Knowledge (TPACK) in the classroom due to the lack of high server internet and lack of well- managed ICT friendly classroom. TPACK refers to every faculty member of the university should be competent in ICT, pedagogy, andragogy, and heutagogy as well as the knowledge on the contents of particular subject matter. As such, the teachers can take charge of any academic responsibility.

\section{Participation in the Curriculum Development}

Tribhuvan University is the largest and oldest university among the eleven young universities in Nepal. There are not bottom-up practices of curricula designing of different subjects in B.Ed and M.Ed levels. One of respondents T7 argues that

the designing of the syllabuses of English Education in bachelor and master are not given complete authority and responsibility to the chairperson of English education with full-fledged autonomy as well. The dean's office of faculty of education should form the autonomous committee under the chairmanship of subject committee with adequate financial support for modifying and developing the curricula of English education in B.Ed and M.Ed levels.

There is no absolute autonomy of curriculum development, and modification to the concerned subject teachers who have been teaching the particular subject for a long time. If all of the subject teachers who have been assigned to teach in the classroom were involved in the process of curriculum designing and modification, there would be great respect to the autonomy of teachers thereby growing their professional competence through this practice (Wilches, 2007, as cited in Poulsrud, 2018). In this regard, T6 states that "there is still practicing of top to bottom exercises 
of curriculum designing in the B.Ed and M.Ed levels majoring in English Education at Tribhuvan University". In fact, teacher autonomy in the curriculum development should be afforded to the students, parents, subject teachers, subject experts, and authority of the university. If the subject teachers were given autonomy in designing the syllabuses, contents and materials, there would be growth and development of professional competences of teachers.

\section{Partaking in Conference, Seminar and Workshop}

Teachers need to be self-directed in order to develop professionalism. The image and development of academic institution is based on what types of teaching staff have been working in the institution. In order to promote the results of the colleges, the teacher professional development should be emphasized by each institution. If the teachers were professionally sound in their subject matters, the teaching and learning would be certainly promoted. Promoting professional competence, teachers should be given autonomy to present paper and to take part in the workshops, symposiums, conferences and seminars of the concerned subjects in national, international and local levels. In this regard, T9 states that

I have not got any encouragement to present paper in any conference and workshop of ELT. When my paper was selected abroad for presentation, I applied for travel grants to Rector Office of Tribhuvan University. I have been granted neither travel grants nor unpaid leave from the Rector Office, since then, I have not tried to take part in any type of seminar, conference and workshop at home and abroad.

The university should allocate enough budgets for teachers' travel grants and day allowance to facilitate the interested faculty members to take part in the conference, workshop and seminar organized by professional organizations at home and abroad to develop the professional competence. Teacher autonomy is also self-directed in teaching methods, styles, assessments, doing researches, taking part in conferences, seminars, workshops for their professional development (Little, 1995; Holec, 1981, as cited in Trebbi, 2008).

In this regard, teacher autonomy needs proper mentoring. In this regard, T8 says that "there is no allocation of marks of presentation in the international, national, and local conference, workshop and seminar in promotion for readers and professors in Tribhuvan University Commission Service". Teachers of university should have freedom and encouragement to take part in the conference and workshop hosted by any professional organization for their professional competences.

\section{Involvement in the Policy Making}

To run any college or institution, rules and regulations, norms and values, and policies in the campus level, local and central levels must be formed and regulated. In the course of forming, regulating and maintaining the rules and regulation and polices, there should be active participations and involvement of all teachers in this matter. In this regard, teacher should be granted autonomy in the process of construction of the rules, regulations and policies to conduct examination, to regulate academic administration, and to run any short-term and long-term training, seminar, symposium, and seminar. In this regard, T10 asserts that

Teachers are not respected in course of making and regulating any policies, and rules and regulation. In fact, there is no teacher autonomy in making policies either in campus or university levels thereby being obstacles and hardship to develop their academic leadership skills and to tackle the contextual challenges. 
In fact, teachers are excluded from participating in the process of making policies, rules and laws while modifying and amendment of the statute of Tribhuvan University. Had the teachers actively involved in this regard, they would get ample opportunities for their professional development. Teachers autonomy can be fostered if they get chance to play the roles of curriculum designers, administrators, assessor etc. (Schibeci \& Hickey, 2003). Teachers' leadership and management would be enhanced if they were involved in policy making process

\section{Impact of Teacher Autonomy and Professional Competence}

Teacher autonomy promotes the professional competence vice versa. In this regards, one of the participants T9 argues that "regulation and maintenance of teacher autonomy promotes the self-esteem and self-respect of the teachers so that they can develop their confidence, and selfefficacy. Most of teachers were encouraged to present paper at home and abroad. They would attempt to publish their articles in the journal at home and abroad." If the university teachers were granted full-fledged teacher autonomy like course designing, freedom of syllabus designing and prescribing the books, selection and gradation of content, freedom of paper presentation home and abroad etc. their professional development automatically would be developed.

\section{Conclusion}

Teacher autonomy for teacher professional competence is essential for the quality development of any academic institution as well as professional growth of its faculty members at the university. Rector Office should play a vital role to motivate them to attend and present the papers in the conferences, workshops, and seminars at local, national and international levels for their professional competences. It is argued that taking part in seminar and conference is essential for teacher autonomy, thereby developing their professional competences. Due to the lack of autonomy in making policies either in the constituent colleges or university campus, teachers encounter obstacles and hardships to develop their leadership skills and to tackle the contextual challenges. Teacher autonomy has not been practiced in tertiary and post graduate levels at Tribhuvan University. There are no substantial practices of teacher autonomy at the constituent colleges and university campuses of Tribhuvan University. In my reflection, teacher autonomy is essential for the professional growth of faculty members of English education. The quality of education of any institution is based on the academic performance of the teachers which can be enhanced through granting the teacher autonomy. There is interrelation between teacher autonomy and professional competence of the teachers.

Author' Biography: Dr. Purna Bahadur Kadel has been teaching as an associate professor at Central Department of Education, Tribhuvan University, Kathmandu, Nepal. He has earned $\mathrm{PhD}$ in English Education from The English and Foreign Languages University, Hyderabad, India. His major interest areas are teacher professional development, critical discourse analysis, teaching language through literature etc. Moreover, he has served as an editor of the NELTA journal from 2017 to 2020.

\section{References}

Benson, P. (2001). Teaching and researching autonomy in language learning. London: Longman.

Benson, P. (2000). Autonomy as learners' and teachers' right. In B. Sinclair, I. McGrath and T. E. Lamb (Eds.), Learner autonomy, teacher autonomy: Future Direction, (p.p.11-117). London: Longman. 
Benson, P. (2008). Teachers and learner' perspective on autonomy. In Terry Lamb and Hay Reinders (Eds.), Learner and teacher autonomy. Philadelphia: John Benjamins B.V.

Castle, K. \& Aichele, D. B. (1994). Professional development and teacher autonomy. In D.

B. Aichele and A. F. Oxford (Eds.), Professional development for teacher of Mathematics (pp.1-8) Reston, VA: National Council of Teachers of Mathematics.

Cohen, L., Manion, L., \& Morrison, K, (2007). Research Methods in Education. New York: Taylor \& Francis Group.

Dikilitas, K. \& Griffiths, C. (2017). Developing language teacher autonomy through action research. E-book. Palgrave Macmillan.

Fachrurrazi (2017). Relationship between professional competences and teacher work-autonomy. Unpublished master's thesis in education. University of Tampere Aceh, Indonesia. Retrieved from www.oatd.org, on $12^{\text {th }}$ May, 2020.

Jaime, U. W. (2007). Teacher autonomy: A critical review of the research and concept beyond Applied Linguistics. Ikala Revista de Lenguage Culture, 12(18), 245-275. Retrieved from http://www.redalyc.org/articulo.oazid 2555020488010 on 14th, Sep. 2019.

Little, D. (1995). Autonomy in language learning as dialogue: the dependence of learner autonomy on teacher autonomy. System, 23 (2), 175-182.

Paulsrud, D. (2018). Teacher autonomy in Sweden and Finland: Investigating decision-making and control comparatively. Unpublished $\mathrm{PhD}$ dissertation, Uppsala University. Retrieved from http://urn.kb.se/resolve?urn=urn:nbn:se:uu:diva-356793 on Sep. 2019.

Prakash, V. (2011). Concerns about autonomy and academic. Economic and Political Weekly, 46(16) 36-40.

Schibeci, R. A. \& Hickey, R. L. (2003). Dimension of autonomy: Primary teachers' decisions about involvement in Science professional development. Science Education, 88, 119145 .

Sehrawat, J. (2014). Teacher autonomy: Key to teaching success. Bhartiyam International Journal, 4 (1), 1-8.

Shaw, J. (2017). Teachers working together: What do we talk about when we talk about autonomy? In Terry Lamb and Hay Reinders (Eds.), Learner and teacher autonomy. Philadelphia: John Benjamins B.V.

Smith, R. C. (2003). Teacher education of teacher-learner autonomy. In J. Gollin et al. (Eds.), Symposium for language teacher educators: Paper from three LALS Symposia (pp. 1-13) Edinburg: LALS, University of Edinburgh. Retrieved from http www. warwick ac uk/nelsdr/ teacher autonomy pdf.

Trebbi, T. (2008). Freedom- a prerequisite for learner autonomy. In Terry Lamb and Hay Reinders (Eds), Learner and teacher autonomy. Philadelphia: John Benjamins B.V.

Vieira, F., Barbosa, I., Paiva, M., \& Fernandes, I. S. (2008). Teacher education towards teacher autonomy: Concepts, realities and responses. (Vol.1, p. 217). Amsterdam: John Benjamins Pub. Co. 